Limnol. Rev. (2016) 16, 1: 41-50

\title{
Ecological status of urban ponds in Białystok, Poland
}

\author{
Elżbieta Jekatierynczuk-Rudczyk, Piotr Zieliński, Katarzyna Puczko \\ Department of Environmental Protection, University of Białystok, Ciołkowskiego 1J, 15-245 Białystok, Poland, \\ e-mail: rudczyk@uwb.edu.pl (corresponding author)
}

\begin{abstract}
Stawy Dojlidzkie (The Dojlidy Ponds) are located in the north-eastern part of Poland, near the capital of the Podlasie province, in Białystok. The Dojlidy Ponds (DP) are a complex of more than 20 reservoirs arranged adjacent to one another in an area of about 140 hectares. The largest recreation reservoir (Plażowy) is located within the city limits. Its total area is 34 hectares, it has a capacity of $597040 \mathrm{~m}^{3}$ and a maximum depth of approximately $2.5 \mathrm{~m}$. DP are supplied by a tributary of the Dojlidy Górne and the River Biała, the principal river of Bialystok. Water tests of a limnic and lenitic character in the upper part of River Biała catchment in Bialystok were conducted from March to October 2014. Referring the obtained results to the actual norms, it can be concluded that most of the parameters analyzed in DP can be assigned to the first class of surface waters. Exceptions were the iron ions, orthophosphates (SRP), total phosphorus (TP), Kjeldahl nitrogen, and also water color and DOC. According to the evaluation of trophic status, the water of DP is eutrophic. The average value of TSI was 55 in the water of the tested objects. The obtained results show that the ecological status of water in the largest pond within the DP complex, in accordance with, the Ecological State Macrophyte Index (ESMI) represent to the good state.
\end{abstract}

Key words: ecological status of water, trophic status, ESMI

\section{Introduction}

Small water bodies, both natural and those created due to human activities, are an essential component of the urban environment. They offer great spatial variety and affect many environmental characteristics. The constant presence of surface water modifies the microclimate and reduces the amplitude of temperature and humidity (Kajak 1998). Water bodies and the surrounding vegetation are an integral part of the urban ecosystem, and contribute to growth in biodiversity. In addition, they affect aesthetic appearance and the development of recreation in a city. They can also act as receivers of rainwater and various substances, including toxic ones (Jarosiewicz et al. 2012). Due to their typically small depth, the bottom of such ponds is completely covered with water vegetation.

The Dojlidy Ponds (DP) in Białystok are an example of waters of limnic character within urban areas. The construction of artificial water reservoirs in the vicinity of settlements has always been driven by water retention for economic purposes. The origins of water retention in Dojlidy date back to the activity of Klemens Branicki in Białystok and neighboring areas (Dobroński 2010). In the interwar period they served as breeding ponds. Based on the existing fish ponds in Dojlidy, another big investment began in 1933, i.e. construction of a swimming area in Dojlidy. The bathing beach was opened in May 1936 and its role of recreation and sports was restored in the 60-70's of the twentieth century (Dobroński 2012). The Sports Club was created on the largest reservoir (Plażowy). Its current shape and the recreation facilities offered there are primarily due to a thorough modernization, completed in 2014. During the development of the recreational and sports complex several reclamation treatments were performed, including mowing the submersed macrophytes and cleaning the bottom.

The aim of these studies was to: (i) assess the current hydrochemical and ecological status of the Dojlidy Ponds, and (ii) indicate the anthropogenic threats to the aquatic environment in the southeastern area of Białystok. 


\section{Study area}

$\mathrm{DP}$ are located in the north-eastern part of Poland, near the capital of the Podlasie province, in Białystok. The pond complex is situated on the southeastern edge of the town, in the Dojlidy outskirts. In hydrological terms, the study area belongs to the Vistula river catchment. Białystok city is situated within the third-order catchments: of rivers Supraśl and Horodnianka, that are the right-hand tributaries of the Narew River. A fourth-order catchment can also be distinguished, including rivers: Biała, Jaroszówka, Karakulanka, the Wesolowski, Pietraszowski watercourses, as well as a fifth-order belonging entirely to the Biała River catchment, including: the Dolistówka, Bażantarka, and 15 small, unnamed watercourses (Kwiatkowski and Gajko 2011) (Fig. 1). Most of them have a periodic nature and they function only during periods of increased precipitations and winterspring melt.
An important element influencing the nature of the functioning of the Białystok rivers is the drainage system covering $47.35 \%$ of the city (Kwiatkowski et al. 2004). This contributes to an unnatural shaping of the rivers' flow rate (as much as a several-fold increase during heavy rainfall), and also affects the deterioration in water quality of streams (Jekatierynczuk-Rudczyk and Zieliński 2007). The sewer system also interferes with the surface runoff due to the terrain within the river catchment.

DP in Białystok are a complex of more than 20 water reservoirs arranged adjacent to one another in an area of about 140 hectares. The largest water reservoir (Plażowy) is located within the city limits. Its total area is 34 hectares, it has a capacity of $597040 \mathrm{~m}^{3}$ and a maximum depth of about $2.5 \mathrm{~m}$. The Plażowy reservoir was created by damming the water level up to $136.5 \mathrm{~m}$ a.s.l. (Kwiatkowski et al. 2004). The southwestern part of the shore is utilized for recreation. There is a city beach, a playground for children, and

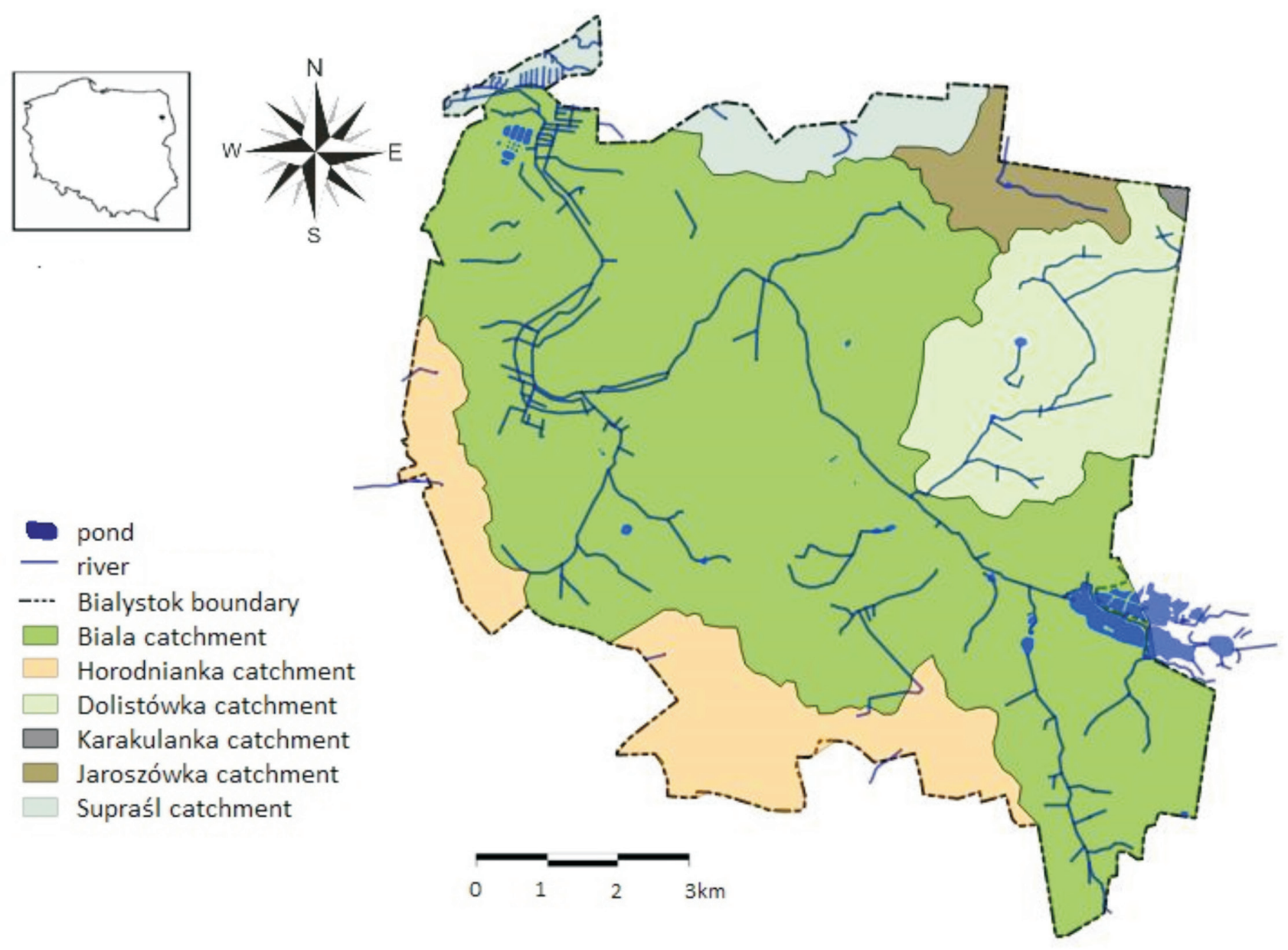

Fig. 1. Map of hydrographic division of the area of Białystok city 
swimming equipment. The reservoir has an important recreational function, and is also used by anglers.

DP are supplied by a tributary of the Dojlidy Górne and Biała River, the principal river in Białystok (Kwiatkowski and Gajko 2011). It originates from the wetlands near the village Protasy at an altitude of 157 $\mathrm{m}$ a.s.l. The area of the whole catchment is equal to $133.37 \mathrm{~km}^{2}$. The Biała River is a left-hand tributary of the Supraśl River. Its length is $32.7 \mathrm{~km}$ (including about $20 \mathrm{~km}$ within the city of Białystok). The river flows in a north-western direction. The Biała has 18 tributaries, of which the Bażantarka and Dolistówka watercourses flowing from Dojlidy Górne are of a permanent nature (Czarnecka 2005a, b).

Due to anthropogenic activity, the morphology of the direct catchment of the Dojlidy Ponds has been significantly transformed. The ponds are surrounded by forest complexes, fields and meadows. A system of drainage ditches, which are located in the eastern part of the DP complex, drain all the water from adjacent areas to the ponds.

The Dojlidy Ponds possess high biotic potential, which predisposes them to conservation protection.

\section{Methods}

Water researches of a limnic and lenitic character in the upper part of Biała River catchment in Białystok were conducted from March to October 2014. Water from the tributaries of DP (watercourses near: Dojlidy,Kuriany, Sobolewo, several ponds, and the Biała River below DP) was sampled for hydrochemical analyses. During the summer, investigations macrophytes were additionally carried out on six sites of Plażowy pond (Fig. 2).

In the field, a multi-parameter probe by HachLange was used to measure the temperature, electrolytic conductivity (EC), dissolved oxygen concentration, oxygen saturation of water, reaction $(\mathrm{pH})$, and redox potential (Eh). Water samples were subject to hydrochemical analysis in the laboratory of the Department of Environmental Protection, University in Białystok by using of methods proposed by Hermanowicz et al. (1999). The following items were determined: total hardness, bicarbonates $\left(\mathrm{HCO}^{3-}\right)$, calcium $\left(\mathrm{Ca}^{2+}\right)$, sodium $\left(\mathrm{Na}^{+}\right)$, potassium $\left(\mathrm{K}^{+}\right)$, sulfates $\left(\mathrm{SO}_{4}{ }^{2-}\right)$, chlorides $\left(\mathrm{Cl}^{-}\right)$, silicates $\left(\mathrm{SiO}_{2}^{-3}\right)$ ammonium $\left(\mathrm{N}^{-} \mathrm{NH}_{4}^{+}\right)$, nitrites and nitrates $\left(\mathrm{N}-\mathrm{NO}_{2}^{-}, \mathrm{N}-\mathrm{NO}_{3}^{-}\right)$, orthophosphates (SRP), dissolved fraction of phosphorus (DFP), total phosphorus (TP). Magnesium concentration $\left(\mathrm{Mg}^{2+}\right)$ was calculated as the difference between total hardness and calcium concentration.

Total nitrogen was analyzed in a Kjeldahl analyzer by Tecator 2300. Mineral nitrogen (TIN) was calculated as the sum of $\mathrm{N}-\mathrm{NH}_{4}^{+} \mathrm{N}-\mathrm{NO}_{2}{ }^{-}$and $\mathrm{N}-\mathrm{NO}_{3}{ }^{-}$. Organic nitrogen (TON) was calculated from the difference between Kjeldahl total nitrogen and ammonia. Total nitrogen (TN) was calculated as the sum of organic and mineral nitrogen. Dissolved organic carbon concentration (DOC) was determined by applying an analyzer by Shimadzu TOC-5050A with an IR detector of $\mathrm{CO}_{2}$. Aromaticity of organic matter (SUVA)

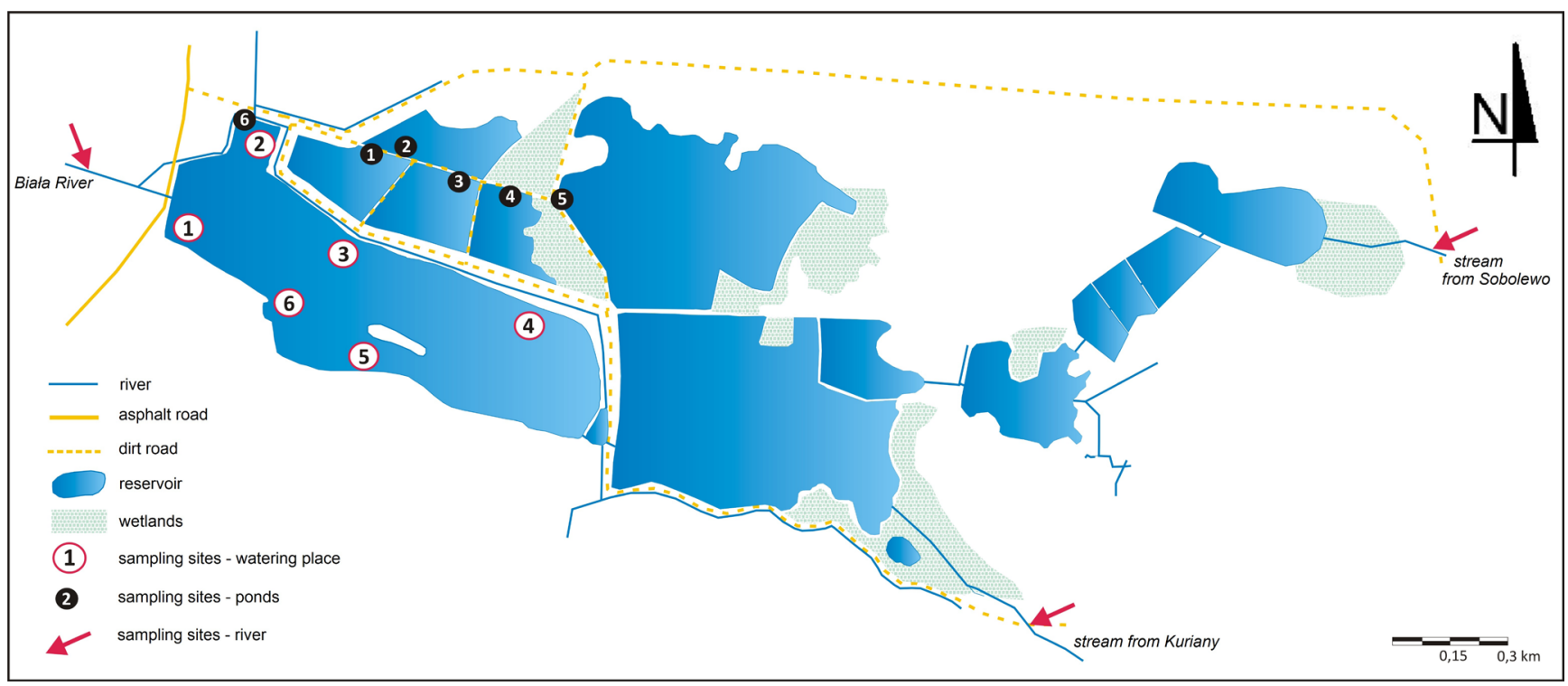

Fig. 2. Dojlidy Ponds (DP) in Białystok 
was calculated according to the formula: $\mathrm{SUVA}_{260}=$ $\mathrm{Abs}_{(1=260)} \times 1000 / \mathrm{DOC}\left[\mathrm{dm}^{3} \mathrm{~g} \mathrm{C}^{-1} \mathrm{~cm}^{-1}\right]$. Iron fractions were determined spectrophotometrically using 1.10-phenantroline, while manganese was determined in the presence of formaldoxime. Five phosphorus, manganese and iron fractions were distinguished: total fraction (TP, TMn, TFe), dissolved fraction (DP, DMn, $\mathrm{DFe}$ ), soluble reactive fraction (SRP, SRMn, SRFe), dissolved organic fraction (DOP, DOMn, DOFe), and particle fraction (PP, PMn, PFe).

Carlson's Trophic State Index (TSI) was applied to assess the trophic status of DP (Carlson 1977). The ecological status evaluation was by on the macrophyte indicator ESMI (Ecological State Macrophyte Index). A study of the macrophytes in Plażowy pond was carried out in August 2014 at six transects designated in the littoral.

Statistical processing was performed with Statgraphics 5.0 for Windows software. Statistical significance of differences was calculated by means of multiple comparisons using the Duncan test.

\section{Results and Discussion}

\section{Assessment of ecological status of DP}

Through a variety of economic activities in urban areas humans have often intervened in natural hydrological and biological processes, disturbing their balance (Puczko et al. 2014). Multilateral human activities in urban areas generally lead to the degradation of the aquatic environment understood as a whole (Kaniecki 2014). City expansion has led to significant transformation in aquatic ecosystems. The hydrographic network in urban areas is heavily distorted and the natural water cycle is disturbed. The loss of hydraulic contact with groundwater and lack of connection with the drainage catchment is a common consequence of river regulation. A consequence of anthropogenic pressure, among other issues, is the disappearance of the flow in rivers, and thus the degradation of wetland ecosystems. Water reservoirs located in urban areas are characterized by a depleted taxonomic structure of organisms and deterioration of water quality (Kuczyńska-Kippen et al. 2004).

Ecological status is determined in natural watercourses, lakes or other natural reservoirs, transitional and coastal waters. The assessment is based on the results of the classification of physicochemical, biological and hydro-morphological elements. The ec- ological status is defined as: very good, good, moderate, poor, and bad (EWFD 2000; MŚ 2014). Studies on the ecological status of standing waters in urban areas in Poland are performed more and more frequently. The objects of such studies to date have included: Lake Klasztorne in Kartuzy (Gutowski et al. 1982), Lakes Podkowka (Grochowska and Dunalska 2005) and Kortowskie in Olsztyn (Mientki 1977), Lake Zajezierskie in Sztum (Marszelewski 2005), and Lake Domowe in Szczytno (Gawrońska and Lossow 2005). The quality of the surface stagnant water in urban areas varies and depends on the type of economic activity as well as functions of the water reservoir. Different types of anthropogenic hazards are increasingly eliminated and water in urban areas is subjected to renaturization (Gorączko 2007; Puczko and Jekatierynczuk-Rudczyk 2014).

\section{Hydrochemical assessment of DP}

Surface waters and groundwater in Białystok have been significantly transformed over the decades. Owing to anthropopressure, small fragments of streams, natural Lake Bagno, oxbow lakes, and many natural groundwater outflows have disappeared from the city (Jekatierynczuk-Rudczyk 2008). Urban development has encroached on areas that in former years were river valleys. Drainage has led to the drying out of large areas that have now been turned into housing developments. At the same time, a number of canals and artificial reservoirs of stagnating water that perform various socio-economic functions, have been constructed. Marked transformations in the hydrography of surface and groundwater along with pollution of anthropogenic origin have resulted in the destruction of natural processes occurring in water, including the processes of self-purification (Puczko et al. 2014). Water quality has been converted along with the change in water balance.

The physical traits of DP water show a general similarity (Table 1). The lowest average value of electrolytic conductivity in DP water not exceeding $500 \mu \mathrm{S}$ $\mathrm{cm}^{-1}$ is worth mentioning. A slight differentiation in the average concentration of macronutrients is a consequence of a negligible EC differentiation in the DP catchment (Table 1). The Biała River below DP revealed the largest values of mean $\mathrm{Ca}^{2+}, \mathrm{Cl}^{-}$, and $\mathrm{SiO}_{3}{ }^{2-}$ concentrations. Despite the lack of statistically significant differences between levels of iron and manganese in the investigated types of water in the upper part of the Biała Biała catchment, a slightly different structure of 
Table 1 . The water quality characteristics in the Dojlidy Ponds catchment $(\mathrm{p}<0,05)$

\begin{tabular}{|c|c|c|c|c|}
\hline \multirow{3}{*}{ Parameter } & Tributaries of Dojlidy Ponds & Dojlidy Ponds (DP) & Biała River & \multirow{3}{*}{$\begin{array}{c}\text { Statistical } \\
\text { significance o } \\
\text { differences }\end{array}$} \\
\hline & $\mathrm{n}=9$ & $\mathrm{n}=18$ & $\mathrm{n}=4$ & \\
\hline & 1 & 2 & 3 & \\
\hline \multirow{2}{*}{ Temperature $\left[{ }^{\circ} \mathrm{C}\right]$} & 1.1-21.1 & 1.6-24.2 & 1.9-19.4 & \\
\hline & 9.2 & 13.7 & 10.1 & \\
\hline \multirow[t]{2}{*}{$\mathrm{pH}$} & $\underline{6.4-8.7}$ & $\underline{6.4-8.5}$ & $\underline{6.57 .9}$ & \\
\hline & 7.6 & 7.8 & 7.4 & \\
\hline \multirow{2}{*}{$\mathrm{EC}\left[\mu \mathrm{S} \mathrm{cm} \mathrm{cm}^{-1}\right]$} & $239-680$ & $\underline{290-668}$ & $\underline{639-791}$ & 1323 \\
\hline & 508 & 481 & 684 & $1-3,2-3$ \\
\hline \multirow{2}{*}{ Oxygen [mg dm ${ }^{-3}$ ] } & $\underline{6.3-12.1}$ & $\underline{4.3-16.8}$ & $\underline{7-11.2}$ & \\
\hline & 9.3 & 9.7 & 9.2 & \\
\hline \multirow{2}{*}{ Saturation [\%] } & $\underline{67-87}$ & $\underline{47-132}$ & $\underline{78-86}$ & \\
\hline & 79 & 89 & 81 & \\
\hline \multirow{2}{*}{ Water color $\left[\mathrm{mg} \mathrm{Pt} \mathrm{dm}^{-3}\right]$} & $9.2-96.8$ & $9.2-70.3$ & $9.7-43.3$ & \\
\hline & 32.3 & 33.2 & 31.1 & \\
\hline \multirow{2}{*}{$\mathrm{Ca}^{2+}\left[\mathrm{mg} \mathrm{dm}^{-3}\right]$} & $\underline{51.3-111.2}$ & $\underline{50.4-134.8}$ & $\underline{98.3-121.0}$ & \\
\hline & 93.5 & 80.0 & 109.8 & $2-3$ \\
\hline \multirow{2}{*}{$\mathrm{Mg}^{2+}\left[\mathrm{mg} \mathrm{dm}^{-3}\right]$} & $2.3-30.7$ & 7.6-31.4 & $1.5-16.8$ & \\
\hline & 16.7 & 18.5 & 11.6 & \\
\hline \multirow{2}{*}{$\mathrm{HCO}_{3}^{-} \cdot\left[\mathrm{mg} \mathrm{C} \mathrm{dm}^{-3}\right]$} & $\underline{18-99}$ & $\underline{13-86}$ & $\underline{49-77}$ & \\
\hline & 61 & 52 & 66 & \\
\hline \multirow{2}{*}{$\mathrm{SO}_{4}^{2-}\left[\mathrm{mg} \mathrm{dm}^{-3}\right]$} & $\underline{38.8-119.5}$ & 13.3-118.2 & $\underline{55.2-92.1}$ & \\
\hline & 83.6 & 59.2 & 75.0 & \\
\hline \multirow{2}{*}{$\mathrm{Cl}^{-}\left[\mathrm{mg} \mathrm{dm}^{-3}\right]$} & 15.8-26.9 & $19.1-47.6$ & $29.9-59.7$ & \\
\hline & 21.4 & 28.9 & 39.9 & $1-2 ; 1-3 ; 2-3$ \\
\hline \multirow{2}{*}{$\mathrm{SiO}_{3}^{2-}\left[\mathrm{mg} \mathrm{dm}^{-3}\right]$} & $\underline{0.04-1.80}$ & $\underline{0.14-1.10}$ & $\underline{0.83-2.13}$ & \\
\hline & 0.98 & 0.50 & 1.36 & $1-2 ; 2-3$ \\
\hline \multirow{2}{*}{$\mathrm{TFe}\left[\mathrm{mg} \mathrm{dm}^{-3}\right]$} & $\underline{0.06-1.28}$ & $\underline{0.13-2.86}$ & $\underline{0.07-1.85}$ & \\
\hline & 0.73 & 1.05 & 0.88 & \\
\hline \multirow{2}{*}{ TMn $\left[\mathrm{mg} \mathrm{dm}^{-3}\right]$} & $\underline{0.01-1.01}$ & $\underline{0.01-0.32}$ & $\underline{0.01-0.34}$ & \\
\hline & 0.17 & 0.08 & 0.17 & \\
\hline \multirow{2}{*}{$\mathrm{N}-\mathrm{NH}_{4}^{+}\left[\mu \mathrm{g} \mathrm{N} \mathrm{dm}{ }^{-3}\right]$} & $\underline{123-227}$ & 79-207 & 16-254 & \\
\hline & 164 & 135 & 129 & \\
\hline \multirow{2}{*}{$\mathrm{N}-\mathrm{NO}_{3}^{-}\left[\mu \mathrm{g} \mathrm{N} \mathrm{dm}^{-3}\right]$} & 75-849 & $\underline{19-1175}$ & 71-841 & \\
\hline & 484 & 178 & 429 & $1-2$ \\
\hline $\mathrm{N}-\mathrm{NO}-\left[\mathrm{ug} \mathrm{N}^{-3}\right]$ & $1-14$ & $\underline{0.4-2}$ & $\underline{3-7}$ & 12 \\
\hline 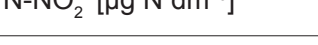 & 2 & 1 & $\overline{4}$ & $1-2$ \\
\hline & $\underline{657-2082}$ & $\underline{912-3289}$ & $1313-3480$ & \\
\hline 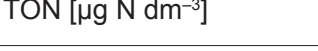 & 1332 & 1597 & 2328 & \\
\hline & 936-2977 & $1181-3542$ & 2106-3767 & \\
\hline $\mathrm{IN}\left[\mu \mathrm{g} \mathrm{N} \mathrm{dm}^{-3}\right]$ & 1923 & 1897 & 3011 & $1-3,2-3$ \\
\hline & $\underline{21-238}$ & $\underline{5-573}$ & 74-722 & \\
\hline $\mathrm{TP}\left[\mu \mathrm{g} \mathrm{dm^{-3 } ]}\right.$ & 124 & $\overline{116}$ & 280 & $1-3,2-3$ \\
\hline & 14-182 & $\underline{6-174}$ & 39-190 & \\
\hline $\mathrm{DFP}\left[\mu \mathrm{g} \mathrm{dm}^{-3}\right]$ & 80 & 58 & 100 & \\
\hline SRP [ $\left.\mathrm{ug} \mathrm{dm}^{-3}\right]$ & $\underline{8-129}$ & $\underline{2-31}$ & $\underline{32-88}$ & \\
\hline $\mathrm{SRP}\left[\mu \mathrm{g} \mathrm{dm}^{-\infty}\right]$ & 46 & $\overline{13}$ & 59 & \\
\hline & $\underline{3-174}$ & 1-168 & $\underline{8-158}$ & \\
\hline $\mathrm{DOP}\left[\mu \mathrm{g} \mathrm{dm^{-3 } ]}\right.$ & 43 & 46 & 53 & \\
\hline & $\underline{6-94}$ & $\underline{0.5-428}$ & $\underline{15-609}$ & \\
\hline$P P\left[\mu g^{2} m^{-3}\right]$ & $\overline{44}$ & 58 & 181 & $1-3,2-3$ \\
\hline $\mathrm{nOC}\left[\mathrm{mg} \mathrm{dm}^{-3}\right]$ & 5.34-22.0 & $\underline{6.22-16.50}$ & 7.38-9.68 & \\
\hline$D \cup C\left[\mathrm{mg} \mathrm{am}^{-}\right]$ & 9.55 & 12.42 & 8.60 & \\
\hline & 8.86-28.95 & $\underline{11.53-30.13}$ & $\underline{9.31-25.59}$ & \\
\hline $\operatorname{SUVA}_{260}\left[\mathrm{dm}^{3} \mathrm{~g} \mathrm{C}^{-1} \mathrm{~cm}^{-1}\right]$ & 20.70 & 21.07 & 19.15 & \\
\hline & $\underline{0.31-7.80}$ & $\underline{0.61-9.20}$ & $\underline{0.58-5.20}$ & \\
\hline Phenols [mg dm-3] & 1.84 & 2.44 & 1.84 & \\
\hline
\end{tabular}


these macronutrients was recorded. More than $30 \%$ of total iron consisted of reactive mineral iron in the tributaries of DP, while its share decreased to below $20 \%$ in the water of ponds and the Biała River (Fig. 3a, b).

Water from the tributaries supply DP with considerable amounts of mineral nitrogen. In ponds, mineral nitrogen is converted into organic form, a symptom of which is the increase in average TON concentration in DP and the Biała River below DP. The highest mean content of $\mathrm{N}-\mathrm{NH}_{4}$ in the upper part of the Biała River catchment was found in tributaries $(164 \mu \mathrm{g}$ $\left.\mathrm{N} \mathrm{dm}^{-3}\right)$, while the lowest $\left(129 \mu \mathrm{g} \mathrm{N} \mathrm{dm}^{-3}\right)$ in the River Biała. The highest average concentration of nitrates was determined in tributaries $-484 \mu \mathrm{g} \mathrm{N} \mathrm{dm}{ }^{-3}$. Water of the Biała River was characterized by similar mean content. DP contained a much lower level of $\mathrm{N}-\mathrm{NO}_{3}$, amounting to $178 \mu \mathrm{g} \mathrm{N} \mathrm{dm}{ }^{-3}$. Remarkably lower concentrations of mineral nitrogen in water of a limnic character confirm its utilization for living processes

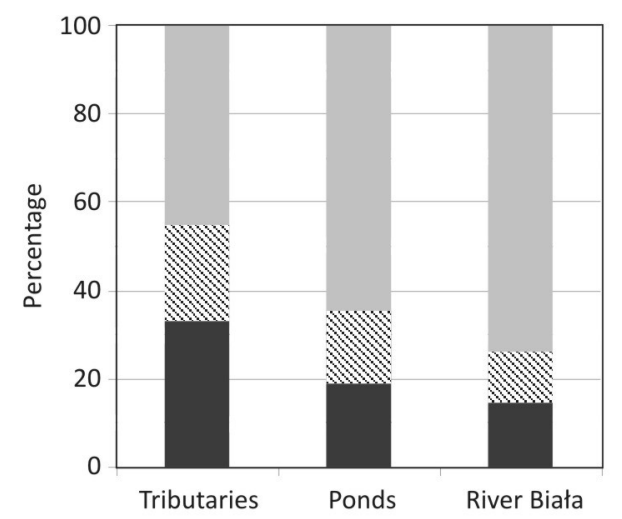

A

- SRFe $\approx$ ODFe $\square$ PFe

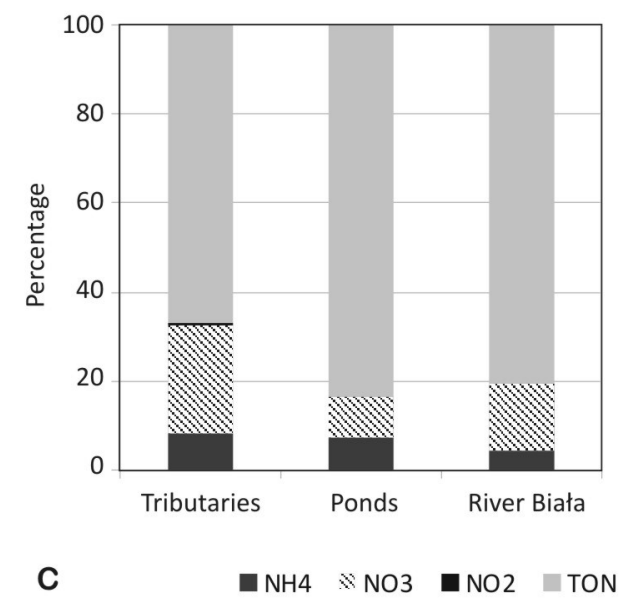

of plants, mainly during the growing season. Mean content of nitrites in the studied water was low, ranging from 1 to $4 \mu \mathrm{g} \mathrm{N} \mathrm{dm}^{-3}$. Average concentrations of some nitrogen compounds significantly differed in the invesigated water types (Table 1). The highest mean TP quantity was found in the Biała River - $280 \mu \mathrm{g} P$ $\mathrm{dm}^{-3}$. In tributaries and DP, average TP concentration oscillated at around $120 \mu \mathrm{g} \mathrm{P} \mathrm{dm}{ }^{-3}$. The highest mean concentrations of dissolved, reactive, organic dissolved, and particle phosphorus were determined in the Biała River. Spatial diversity of mean phosphorus concentrations in the upper catchment of the river was small, as confirmed by the multiple comparison test. In the water of DP, the highest average concentration of dissolved organic carbon, phenols, and the largest aromaticity of organic matter were observed (Table 1).

Despite significant differences in levels of certain nitrogen compounds in the studied types of wa-
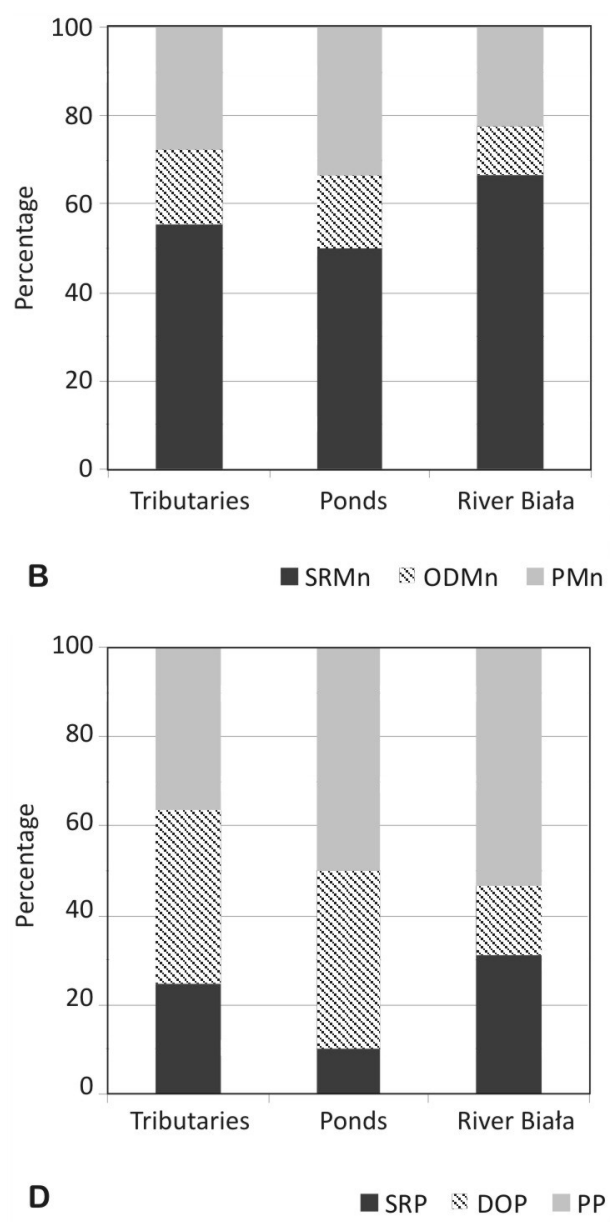

Fig. 3. The structure of iron (A), manganese (B) nitrogen compounds (C) and phosphorus (D) in the Biała River 
ter, its structure is similar (Fig. 3c). A different situation was found in the structure of phosphorus forms, for which waters of DP revealed the lowest share of the SPR (Fig 3d).

Water in the Biała River is systematically tested at two measurement points (in the upper section of the river below DP and at its estuary in Nowy Aleksandrów) by Reginal Inspectorate for Environmental Protection (WIOŚ) in Białystok. On the basis of these measurements, the river is mostly classified into waters of poor ecological status (WIOŚ 2015). Hydrochemical study in the Biała River catchment conducted in 2009-2010 (Wysocka-Czubaszek and Wojno 2014) showed that within the city limits the river is not significantly compromised by the eutrophication process due to the low concentration of biogens, which periodically exceed the limits set for good water quality (nitrates and phosphates). Similar findings were obtained in the framework of the hydrographic development of the Biała River (Tyszewski and Kardel 2009).

Referring the obtained results to the Decree of the Minister of Environment of 22 October 2014, it can be concluded that most of the parameters analyzed in DP can be assigned to class I of surface waters. Exceptions were the iron ions, orthophosphates, total phosphorus, Kjeldahl nitrogen, and also water color and DOC. Hydrochemical changes in urban areas are the result of environmental transformation; and their variability can be very large and sudden. The reclamation treatments in 2014 significantly improved the water quality in Plażowy pond: EC decreased by more than $150 \mu \mathrm{S} \mathrm{cm}^{-1}$, and color of water by $10 \mathrm{mg} \mathrm{Pt} \mathrm{dm}^{-3}$ in comparision to 2013 (Puczko et al. 2014).

\section{Ecological State Macrophyte Index (ESMI) of ponds}

The use of macrophytes to assess the ecological status of lakes in Poland has been carried out by WIOŚ since 2007. The Ecological State Macrophyte Index of lakes allows for the assessment of the current ecological status of a water reservoir (Ciecierska and Kolada 2014) and its classification in terms of the littoral vegetation succession advancement.

In Plażowy pond, average maximum depth of vegetation occurrence was $1.85 \mathrm{~m}$. Mean phyto-littoral coverage amounted to $91.7 \%$, and the total area covered by plants was 31.2 ha. The reservoir has characteristics typical of shallow lakes, in which the greater part of the surface is covered by macrophytes.

The value of the ESMI in DP was 0.449 , which shows that the pond is characterized by good ecologi- cal status (Bok 2009). This value is higher than the result obtained by regional WIOŚ for the eutrophic dam reservoir Siemianówka $(\mathrm{ESMI}=0.383)$. In DP, on six transects, the occurrence of 34 plant communities was identified, which is a large number taking into account the fact that it is a typically urban water body. Only three macrophyte species: Ceratophyllum demersum (L.), Myriophyllum spicatum (L.), Phragmites australis (Cav.) were recorded on all studied transects. Mean coverage of distinguished vegetation communities in the phyto-littoral varied (Table 2). Among listed species, the largest area (34.5\%) was covered by Myriophyllum spicatum (L.). Spiked Water-milfoil is a very common plant which occurs mainly in water abundant in calcium and nutrients, as in the case of water in DP. Accumulated results are similar to those obtained for eutrophic lakes within the region (Ciecierska and Zieliński 2013). These results also correspond with the assessment of the ecological status of the Biała River, where DP are created. In studies conducted a few years earlier, the Biała River, both in the hydro-morphological and macrophyte assessment, presented a good ecological status. Although fewer macrophyte species were recorded in the surrounding ponds the ecological status was good (Bralski 2009). The value of the HQA indicator (Habitat Quality Assessment) of the Biała River in its initial section, i.e. near DP, had features of a moderately anthropogenically transformed riverbed and its average HQA was low amounting 32.1 (Zieliński et al. 2012). The Habitat Modification Score (HMS) reached an average value equal to 20.8 , and its lowest transformation was recorded in the vicinity of DP. A relatively small degree of transformation was reported for the Białystok surroundings, among others, near the studied DP. The municipal part of the Biała River is characterized by a slight differentiation of habitats along its course, which results from the intensive management of its catchment area.

\section{Trophy status assessment of DP water}

The knowledge of a trophic status is a very important indicator of biotic and abiotic conditions in water bodies. Partial water trophy indicators in DP were very uniform. Analyzing the TSI indicator value in the studied ponds, it was found that the lowest results were reported in the case of the indicator based on Secchi disc visibility. The TSI (SD) $_{\text {w }}$ was 51.4. Value of $\mathrm{TSI}_{(\mathrm{CHI})}$ amounted to 56.1, and TSI $\mathrm{TPP}_{(\mathrm{TP})}$ was 57.5. The highest TSI $_{(\mathrm{TP})}$ value is characteristic of water in lakes of the majority of Polish Lakelands (Szymański et al. 
Table 2. Characteristics of the phytolittoral of the main pond of Dojlidy

\begin{tabular}{|c|c|c|c|c|c|c|c|c|c|}
\hline \multirow{2}{*}{ No } & \multirow{2}{*}{ Dominant species in the macrophyte assemblages } & \multirow{2}{*}{ B-B } & \multirow{2}{*}{$\begin{array}{c}\mathrm{ni} \\
{[\%]}\end{array}$} & \multicolumn{6}{|c|}{ Transect } \\
\hline & & & & 1 & 2 & 3 & 4 & 5 & 6 \\
\hline 1 & Abietinella abietina & $r$ & 0.04 & & & & + & & \\
\hline 2 & Bidens tripartita & + & 0.31 & 1 & & & & & + \\
\hline 3 & Carex nigra & $\mathrm{r}$ & 0.04 & + & & & & & \\
\hline 4 & Lythrum salicaria & r & 0.09 & & + & & + & & \\
\hline 5 & Oenanthe aquatica & + & 0.26 & & & & & & 1 \\
\hline 6 & Persicaria amphibia & + & 0.35 & & & + & & 1 & + \\
\hline 7 & Plantago lanceolata & + & 0.31 & & & & + & 1 & \\
\hline 8 & Schoenoplectus lacustris & $\mathrm{r}$ & 0.04 & & & & & & + \\
\hline 9 & Lemna trisulca & + & 0.31 & 1 & & & & & + \\
\hline 10 & Ceratophyllum demersum & 3 & 32.3 & 2 & 5 & 4 & 4 & 4 & 5 \\
\hline 11 & Elodea canadensis & + & 0.52 & & & & & 1 & 1 \\
\hline 12 & Myriophyllum spicatum & 3 & 34.5 & 5 & 2 & 4 & 5 & 5 & 4 \\
\hline 13 & Potamogeton lucens & 1 & 1.83 & & 1 & 2 & & 1 & \\
\hline 14 & Ranunculus circinatus & 1 & 4.45 & & 1 & 1 & 2 & 2 & 2 \\
\hline 15 & Hydrocharis morsus-ranae & 1 & 1.83 & 1 & & & 1 & 2 & \\
\hline 16 & Eleocharis palustris & $\mathrm{r}$ & 0.09 & + & & & & & + \\
\hline 17 & Equisetum fluviatile & + & 0.26 & & & & & 1 & \\
\hline 18 & Eupatorium cannadicum & + & 0.31 & 1 & & & & + & \\
\hline 19 & Glyceria fluitans & r & 0.04 & & & & & & + \\
\hline 20 & Glyceria maxima & + & 0.31 & & & & + & & 1 \\
\hline 21 & Lycopus europaeus & + & 0.79 & 1 & 1 & 1 & & & \\
\hline 22 & Mentha aquatica & + & 0.26 & & & & 1 & & \\
\hline 23 & Phragmites australis & 1 & 4.71 & 1 & 1 & 2 & 2 & 2 & 1 \\
\hline 24 & Rorippa amphibia & + & 0.31 & & & & & 1 & + \\
\hline 25 & Rumex hydrolapathum & + & 0.13 & & + & + & & & + \\
\hline 26 & Scirpus lacustris & + & 0.26 & & & & & 1 & \\
\hline 27 & Scirpus sylvaticus & + & 0.26 & 1 & & & & & \\
\hline 28 & Solanum dulcamara & r & 0.04 & & & & & & + \\
\hline 29 & Sparganium erectum & 1 & 1.61 & & 2 & & & 1 & + \\
\hline 30 & Typha angustifolia & 2 & 12.8 & 1 & 2 & 3 & 3 & 4 & \\
\hline 31 & Typha latifolia & + & 0.31 & & + & & & 1 & \\
\hline 32 & Veronica beccabunga & $r$ & 0.04 & & & & & & + \\
\hline 33 & Carex riparia & r & 0.04 & & & & & & + \\
\hline 34 & Iris pseudacorus & + & 0.26 & & 1 & & & & \\
\hline
\end{tabular}

Braun-Blanquet (B-B) cover-abundance scale: 5 - 75-100\% cover, 4 - 50-75\% cover, 3 - 25-50\% cover, 2 - 5-25\% cover, 1 - abundant, + few individuals, $\mathrm{r}-1-3$ individuals; $\mathrm{ni}$ - mean cover area of the phytolittoral as percentage

2013). Average TSI $=55$ means that DP are eutrophic. Research carried out by Puczko et al. (2014) revealed that TSI in the Plażowy pond was 60.8 , which also allowed this water body to be considered as eutrophic. However in 2014, the TSI was slightly lower. No doubt, reclamation of the reservoir had been advantageous resulting in some decrease of water trophy. Based on the obtained results it can be concluded that the trophic status of DP water (bathing area) had slightly changed. Despite its located in an anthropogenically 
altered areas with relatively intensive recreation. The trophic status of DP is comparable or even slightly better than in urban lakes in Olsztyn (Szymański et al. 2013). The values of TSI obtained for DP are similar to those recorded in the Suwalki Lakeland (Jekatierynczuk-Rudczyk et al. 2014). Large dam reservoirs, usually located outside urban areas, have significantly higher water trophy. A study of the ecological status of surface water in Slupsk indicates their relatively good condition, which is comparable to the aqueous environment of Bialystok (Jarosiewicz et al. 2012).

\section{Conclusions}

Hydrochemical and hydrobiological studies performed in the Dojlidy Ponds allow the following conclusions to be drawn:

Referring the obtained results to the Decree of Minister of Environment of 22 October 2014, it can be said that most of the parameters analyzed in DP qualify the surface water to the first quality class. Exceptions were iron ions, orthophosphates, total phosphorus, Kjeldahl nitrogen, as well as water color and DOC belonging to the third class of water quality.

The ecological status of the largest pond (Plażowy) within the DP complex, according to obtained results based on the Ecological State Macrophyte Index (ESMI), is good.

According to the evaluation of trophic status, water of DP are eutrophic. The average value of TSI was 55 in the water of the tested objects.

By analyzing the concentration of biogens in the direct catchment of DP, it should be said that they are not a threat to the limnic ecosystem functioning in the upper part of the River Biała catchment.

\section{References}

Bok G., 2009, Ocena stanu czystości Zbiornika Siemianówka w 2009 roku (Assessment of purity Reservoir Siemianowka in 2009), IOŚ-WIOŚ Białystok, Białystok, 30 pp. (in Polish).

Bralski M., 2009, Stan ekologiczny rzeki Białej (Ecological status of the Biała River) [Typescript], Wydz. Biologiczno-Chemiczny UwB, Białystok, 111 pp. (in Polish).

Carlson R.E., 1977, A trophic state index for lakes, Limnol. Oceanogr. 22(2): 361-369.

Ciecierska H., Kolada A., 2014, ESMI: a macrophyte index for assessing the ecological status of lakes, Environ. Monit. Assess. 186(9): 5501-5517.
Ciecierska H., Zieliński P., 2013, Roślinność jezior Wigierskiego Parku Narodowego (Vegetation in lakes of the Wigry National Park), [in:] Ciecierska H., Hołdyński C. (eds), Dziedzictwo przyrodnicze Warmii, Mazur i Powiśla (The natural heritage of Warmia, Masuria and Powiśle) Wyd. Mantis, Olsztyn: 221-230 (in Polish).

Czarnecka H. (ed.), 2005a, Atlas podziału hydrograficznego Polski. Cz. 1: Mapy w skali 1:200 000 (Atlas of hydrographic division of Poland. Part 1: Maps in the scale 1:200 000), IMGW, Warszawa (in Polish).

Czarnecka H. (ed.), 2005b, Atlas podziału hydrograficznego Polski. Cz. 2: Zestawienia zlewni (Atlas of hydrographic division of Poland. Part 2: List of catchment basins), IMGW, Warszawa, 558 pp. (in Polish).

Dobroński A.Cz., 2010, Miasto w mieście (City in the city), Medyk Białostocki 89-92: 39-40 (in Polish).

Dobroński A.Cz. (ed.), 2012, Białystok. Historia miasta (Białystok. History of the city), Wydaw. UwB, Białystok, 216 pp. (in Polish).

[EWFD] European Water Framework Directive, 2000, Directive 2000/60/EC of the European Parliament and of the Council of 23 October 2000 establishing a framework for Community action in the field of water policy, Offic. J. Eur. Union L327 43: 1-72.

Gawrońska H., Lossow K., 2005, Restoration of the Domowe lake in Szczytno, Limnol. Rev. 5: 69-73.

Gorączko M., 2007, Wybrane problemy funkcjonowania małych zbiorników wodnych na obszarach zurbanizowanych (Selected problems in the functioning of small water bodies in urban areas), Nauka Przyr. Technol. 1(2): 1-9 (in Polish).

Grochowska J., Dunalska J., 2005, Trophic condition of Lake Podkówka and the drainage basin role in the lake's eutrophication, Limnol. Rev. 5: 93-99.

Gutowski B., Hupka J., Pączkowski P. 1982, Jezioro Klasztorne w Kartuzach - jezioro czy zbiornik ścieków? (Lake Klasztorne in Kartuzy - a lake or sewage tank?), Gosp. Wodna 10 (411): 188-190 (in Polish).

Hermanowicz W., Dojlido J., Dożańska W., Koziorowski B., Zerbe J., 1999, Fizyczno-chemiczne badanie wody i ścieków (Physical-chemical examination of water and wastewater), Wydaw. Arkady, Warszawa, 556 pp. (in Polish).

Jarosiewicz A., Wilkos P., Grunwald D., 2012, Jakość wód stawów miejskich Słupska (Water quality of Słupsk urban ponds), Słupskie Pr. Biol. (SPB) 9: 69-81 (in Polish, English summary).

Jekatierynczuk-Rudczyk E., 2008, Threats to a small river and its urban catchment, Ecohydrol. Hydrobiol. 8(1): 77-87.

Jekatierynczuk-Rudczyk E., Zieliński P., 2007, Charakterystyka jakości wody małej rzeki miejskiej (Characteristics of water quality of small urban river), [in:] Michalczyk Z. (ed.), Obieg wody w środowisku naturalnym i przekształconym (The water cycle in the natural and transformed environment), Wydaw. UMCS, Lublin: 279286 (in Polish, English summary). 
Jekatierynczuk-Rudczyk E., Zieliński P., Grabowska M., Ejsmont-Karabin J, Karpowicz M., Więcko A., 2014, The trophic status of Suwałki Landscape Park lakes on the base of selected parameters (NE Poland)", Environ. Monit. Assess. 186(8): 5101-5121.

Jodłowski A., Gutkowska E., 2012, Ocena stanu troficznego wód Zbiornika Sulejowskiego na podstawie indeksu Carlsona (Sulejow Reservoir Trophic State Assessment on the Basis of Carlson Index), Inż. Ochr. Środ. 15(4): 341-351 (in Polish, English summary).

Kajak Z., 1998, Hydrobiologia-limnologia. Ekosystemy wód śródlądowych (Hydrobiology-limnology. Inland water ecosystems), Wydaw. Nauk. PWN. Warszawa, 360 pp. (in Polish).

Kaniecki A., 2014, Ochrona zasobów wodnych na obszarach miejskich na przykładzie Poznania The protection of water in urbanized areas with city of Poznań as an example), [in:] Ciupa T., Suligowski R. (eds), Woda w mieście (Water in the city), Monogr. Kom. Hydrol. PTG 2, Inst. Geogr. UJK w Kielcach, Kielce: 91-98 (in Polish).

Kuczyńska-Kippen N., Nowosad P., Grzegorz G., 2004, Ocena jakości wód jezior Wielkopolskiego Parku Narodowego oraz zbiorników rekreacyjnych miasta Poznania w okresie wiosennym (Assessment of water quality of lakes in the Wielkopolski National Park and recreational reservoirs in Poznan city in spring), Rocz. AR Pozn. 363, Bot. 7: 193-200 (in Polish).

Kwiatkowski W., Gajko K., 2011, Ekofizjografia Białegostoku. Wstęp i diagnoza stanu środowiska przyrodniczego (Ecophysiography of Białystok. Introduction and diagnosis of the state of the natural environment), Prezydent Miasta Białegostoku, Białystok, 248 pp. (in Polish).

Kwiatkowski W., Gajko K., Ksepko M., Miniuk P., Stepaniuk M., 2004, Opracowanie ekofizjograficzne dla terenu miasta Białegostoku (Ecophysiographical study for Białystok city area), Wydaw. UMB, Białystok, 97 pp. (in Polish).

Marszelewski W., 2005, Zmiany warunków abiotycznych w jeziorach Polski północno-wschodniej (Changes in abiotic conditions in lakes of north-eastern Poland), Wydaw. UMK, Toruń, 280 pp. (in Polish, English summary).

Mientki C., 1977, Chemical properties of Kortowskie lake waters after an 18 years experiment on its restoration. Part II. Dynamics of nitrogen components, Pol. Arch.

Hydrobiol. 24(1):13-24.

[MŚ] Ministerstwo Środowiska (Ministry of the Environment), 2014, Rozporządzenie Ministra Środowiska z dnia 22 października 2014 r. w sprawie sposobu klasyfikacji stanu jednolitych części wód powierzchniowych oraz środowiskowych norm jakości dla substancji priorytetowych (Decree of the Minister of the Environment of 22 October 2014 concerning classification of unit water bodies of surface waters and environmental quality standards for priority hazardous substances): Dz. U. z 2014 r. poz. 1482.
Puczko K., Jekatierynczuk-Rudczyk E., 2014, Dlaczego warto renaturować miejskie rzeki? (Why should restoration of urban river?), Gosp. Wodna 5: 180-188 (in Polish).

Puczko K., Jekatierynczuk-Rudczyk E., Bączek G., 2014, Wpływ antropopresji na jakość wód powierzchniowych Białegostoku (Influence of antropopression on surface water quality in Białystok), [in:] Ciupa T., Suligowski R. (eds), Woda w mieście (Water in the city), Monogr. Kom. Hydrol. PTG 2, Inst. Geogr. UJK w Kielcach, Kielce: 237245 (in Polish).

Szymański D., Dunalska J., Brzozowska R., Sieńska J., Zieliński R., 2014, Ocena stanu troficznego jezior miejskich Olsztyna na podstawie indeksu Carltona (Assessment of the throphic status of urban lakes located in Olsztyn on the basis of the Carlson's index), [in:] Traczewska T.M., Kaźmierczak B. (eds), Interdyscyplinarne zagadnienia w inżynierii i ochronie środowiska, Wydaw. PWroc., Wrocław: 872-881 (in Polish).

Tyszewski S., Kardel I., 2009, Studium hydrograficzne doliny rzeki Białej (Hydrographic study of the River Biała valley) [Typescript], UM w Białymstoku, Białystok, 176 pp. (in Polish).

[WIOŚ] Wojewódzki Inspektorat Ochrony Środowiska (Voivodship Inspectorate of Environmental Protection), 2015, Ocena stanu ekologicznego, potencjału ekologicznego, stanu chemicznego i stanu wód powierzchniowych województwa podlaskiego w 2014 roku. Ocena w Jednolitych Częściach Wód Powierzchniowych (Assessment of ecological status, ecological potential, chemical status and the state of surface water of Podlasie province in 2014. Assessment of surface water bodies), PIOŚWIOŚ Białystok, Białystok, 22 pp. (in Polish).

Wysocka-Czubaszek A., Wojno W., 2014, Sezonowa zmienność chemizmu wody w małej rzece w zlewni zurbanizowanej (Seasonal changes of water chemistry in a small river in an urban catchment), Prz. Nauk. Inż. Kszt. Środ. 63: 64-76 (in Polish, English summary).

Zieliński P., Górniak A., Bralski M., 2012, Wykorzystanie cech hydromorfologicznych do oceny stanu ekologicznego rzeki miejskiej (Ecological status assesment of the urbanized river upplying hydromorphological features), Inż. Ekol. 29: 246-256 (in Polish, English summary). 